\title{
NORMATIVITY OF PRESCRIPTIONS IN ADOLF REINACH'S APRIORISTIC THEORY OF RIGHT
}

\begin{abstract}
In the Logical Investigations, Edmund Husserl defines that which is normative as the objectively regular with its rules of regularity, which can be recognised rationally - normativity concerns the being itself and the rational cognition of the being (logic as a normative discipline establishing the rules of scientific knowledge, as the science of science). Instead, Adolf Reinach in The Apriori Foundations of the Civil Law defines the notion of norm as polysemantic and distinguishes the legal provisions (the prescriptive sentences), formulated within a given community, from the basic norms which are grounded in the objective (including moral) justness of the states of affairs. The obligation of the being and the obligation of acting exist in themselves, independently from cognition. In turn, "enactments and the propositions which express enactments" as a kind of normative sentences have the character of normalisation, but they require a person to pronounce them. The prescriptions realise and refer to what is objectively being and to the objectivity of what is being and obligatory. In my text, I present Reinach's position on the relations between norms and provisions (as prescriptive propositions "which express enactments") referring his theories to the Husserlian concept of normativity.
\end{abstract}

Keywords: description, prescription, law, norm, ideality, ideation.

\section{INTRODUCTION}

The aim of the text is to present Adolf Reinach's position on the relations between norms and enactments (as prescriptive propositions "which express enactments") referring his theses to the Husserlian concept of normativity. In Logische Untersuchungen (1900-1901), Edmund Husserl defines that which is normative as the objectively regular with its rules of regularity, which can be recognised rationally - normativity concerns the being itself and the rational cognition of the being (logic as a normative discipline establishing the rules of scientific knowledge, as the science of science). Instead, in Die apriorischen Grundlagen des bürgerlichen Rechtes (1913), Adolf Reinach defines the notion of norm as polysemantic and distinguishes the legal provisions, i.e. enactments (the prescriptive propositions) formulated within a given community, from the basic norms which are grounded in the objective (including moral) justness of the

*Associate Professor, Polish Academy of Sciences, Institute of Philosophy and Sociology, mgolebiewska@ifispan.edu.pl. 
states of affairs. Reinach argues that: "One should not confuse our apriori theory of right with what has been called 'general legal theory' or 'theory of juristic principles.' Here one cannot speak of an independence from the positive law; the systems of positive law rather form the object of a generalizing and inductive approach" (Reinach 1983, 133; cf. Reinach 1913, 839). The obligation of the being and the obligation of acting exist in themselves, independently from cognition. In turn, provisions, i.e. "enactments and the propositions which express enactments" ("Bestimmungen und Bestimmungssätze") as a kind of normative sentences have the character of normalisation, but they require a person to pronounce them (resp. Reinach 1983, 102; Reinach 1913, 801). The prescriptions realise and refer to what is objectively being and to the objectivity of what is being and obligatory. Reinach writes that: "One has objected to natural law philosophers that they fill out the gaps in the positive law with the 'ideal law' or 'rational law' which beckons to them from a distance, and that they even want to replace explicit positive enactments by this 'higher' law in the event of a contradiction between them. Such an objection would of course not even apply to us. We do not speak of a higher law, but of simple laws of being. As we know, positive legal provisions can deviate from them; but precisely from our point of view it would be meaningless to want to replace the content of efficacious enactments with the essential relations from which the enactments deviate precisely because within the whole context of social interaction they appear to be such that they ought not to be" (Reinach 1983, 135; cf. Reinach 1913, 842).

It must be highlighted that within Reinach's apriori theory of right, one may find a number of elements - assumptions and investigative theses of Husserl's early phenomenology. It is primarily a reference to the normative aspects of logic, to the concept of ideality and the assumptions of essentialism, as present within the Logical Investigations, as well as, to the Husserlian grasp of ideas, with its source being not Platonism but Kantianism - the Kantian concept of regulative ideas. In his article concerning the philosophical assumptions and theses of Reinach, Philipp Mayrhofer argues that: "Far from being a simple return to Plato's universe of ideas, Reinach's project shows through the deduction of a specific phenomenality of essences the limits of the idea of constitution and a fortiori of the ontological foundation" (Mayrhofer 2005, the English abstract of text; cf. Cantegreil 2005).

\section{HUSSERL AND THE NORMATIVE ASPECTS OF LOGIC}

Already in Logische Untersuchungen Edmund Husserl indicated logical necessities as the basis of normativity (e.g. chapters "Logic as a normative and, in particular, as a practical discipline", "Theoretical disciplines as the foundation of normative disciplines", particularly "The concept of a normative science", and 
"Normative disciplines and technologies"; Husserl 2001, resp. 15, 28, 33, 37; [Die Logik als normative und speziell als praktische Disziplin; Theoretische Disziplinen als Fundamente normativer; Der Begriff der normativen Wissenschaft; Normative Disziplin und Kunstlehre]). Furthermore, according to Husserl, normativity, including legal norms, is connected with some subjective need for rules that derive from and are conditional upon transcendental subjectivity - the transcendental function of consciousness. Simultaneously, this subjective need for rules would constitute the basis for establishment of and respect for other people's rights within the borders of one common social and cultural world called intersubjectivity (die Intersubjektivität, die Lebenswelt).

As mentioned, in his work titled Logische Untersuchungen, Edmund Husserl referred to the contemporary conclusions in logic, as well as, proposed his own conclusions regarding mathematical logic, logical propositions, as well as propositions of colloquial language. One of the most important issues touched by Husserl was the matter of meaning - the general assortment of semantic matters pertaining to the very theory of meaning, the semantic function, the semantic (signitive) intention and its fulfilment, and finally - the meaning of mental representation in its relations to the verbal representation and the semiotic representation in general (cf. Simmons 1995). The semantic function is fulfilled in discursive reasoning, in the correlations between propositions. The "presumption" apparent in two propositions does not "denote", that they represent the same object, or that they have identical meaning. Additionally, the inclusion of an object [of cognition] within representations, is not real, but functional and may be comprehended discursively, due to appropriate other identity propositions. Husserl argued: "Universal likeness of content, and constant functional laws of nature which regulate the production of such content, do not constitute a genuine universal validity, which rather rests upon ideality. If all creatures of a genus are constitutionally compelled to judge alike, they are in empirical agreement, but, in the ideal sense demanded by a supra-empirical logic, there might as well have been disagreement as agreement. To define truth in terms of a community of nature is to abandon its notion" (Husserl 2001, 87). Therefore, Husserl makes a distinction between: real, psychological contents of a proposition (comprising of the representing act and the representational content), as well as ideal logical contents, i.e. the meaning and the proper object of a logical proposition. The logical content is fulfilled psychologically within two strings of possible experiences (the act and the contents of the act).

In volume I of his work, Husserl defines meaning in the context of the tasks of pure logic (establishing pure semantic categories, as well as pure objective categories - i.e. the categorial and the reduction to types). In volume II, Husserl disputes with the associative ("psychological") semantic theory, establishes a distinction between expression, pronouncement and naming, discusses the differences between expression and meaning as "ideal unities", between the 
commonly taken meaning of words (the "fluctuation in meaning") and the "ideality of unities of meaning" taken logically, as well as, characterises the ideal unity of semantic experiences and the acts that ascribe meaning (Husserl 2001, 216). Here, Husserl highlights that the ideality of meanings is not an ideality in a normative sense.

The "theory of science" postulated by Husserl, considers ideas, theory and science within its formal regularities (particularly the "methodical modes of procedure", including validations and procedures that require validation). Husserl explains the above as follows: "From our discussions up to this point logic - in the sense of the theory of science here in question - emerges as a normative discipline. Sciences are creations of the spirit, which are directed to a certain end, and which are for that reason to be judged in accordance with that end. [...] Logic seeks to search into what pertains to genuine, valid science as such, what constitutes the Idea of Science, so as to be able to use the latter to measure the empirically given sciences as to their agreement with this Idea, the degree to which they approach it, and where they offend against it. In this logic shows itself to be a normative science, and separates itself off from the comparative mode of treatment which tries to conceive of the sciences, according to their typical communities and peculiarities, as concrete cultural products of their era, and to explain them through the relationships which obtain in their time. For it is of the essence of a normative science that it establishes general propositions in which, with an eye to a normative standard, an Idea or highest goal, certain features are mentioned..." (Husserl 2001, 25). Such is the context - of a pure logic as an apriori, formal and at the same time normative discipline of a "theory of science" - in which the concept of a norm regarded as a certain acknowledged measure of evaluation, is being discussed by Husserl. Husserl emphasises that the ideality of meanings is not an ideality in a normative sense, however, in the first volume, he begins with normativity as the base for the logical proposition and the logical procedures. One must remind that, according to Husserl, norm as a certain measure of a logical proposition refers to its truth or falsehood.

Husserl considers the possibility of the ideality of meanings as a matter of normativity, and admits, that the ideality of meanings is a particular case of the "species ideality in general" - an ideality of internal images in a generalised character. However, it has "not the sense of a normative ideality, as if we were here dealing with an ideal of perfection, an ideal limiting value, over against particular cases which realized it more or less approximately. No doubt the 'logical concept', i.e. the term in the sense of normative logic, is an ideal in respect of its meaning" (Bedeutung) (Husserl 2001, 231). Here, Husserl refers to the logical postulate of absolute strictness, precision and univocalness of logical propositions, however, it can only relate to "what is regulated by prescriptions", to "the formation of meaningful terms, to care in the subjective sifting out and expression of one's thoughts" (Husserl 2001, 231). Meanings "in themselves" however, despite the 
"fluctuation of the act of meaning", are "specific unities", and "they themselves are not ideals. Ideality in the ordinary, normative sense does not exclude reality. An ideal is a concrete original that may exist, and that may confront one in reality" and "even where an ideal is not realizable, it is at least an individual in our presentative intention. The ideality of what is specific is, contrariwise, the complete opposite of reality or individuality; it represents no end of possible endeavour, its ideality lies in a 'unity in multiplicity'. Not the species itself, but the individual falling under it, can be a practical ideal" (Husserl 2001, 231).

Husserl, for the sake of the phenomenological semantic theory, concludes with regard to the argument between realists and nominalists. He debates John Locke's nominalism, once again highlighting the difference between the psychological and the logical grasping of the meaning of expressions, in which the apriori possibility of formulating clauses (logical propositions) is related to a certain necessity (of the unity of meaning) instead of a contingent characteristic for psychological acts ("psychologically contingent acts"; Husserl 2001, 265). The "generality of psychological function", assumed by the nominalists is not a "generality which belongs to the intentional content of the logical experiences themselves", or which "described objectively and ideally, belongs to our meanings and our meaningfulfilments" (Husserl 2001, 264), because this generality is not psychological but essential.

\section{IDEATION, IDEALITY AND IDEA AS CONDITIONS OF MEANING}

\subsection{Edmund Husserl and Roman Ingarden}

According to Edmund Husserl, logic is dedicated to the regularities of the appearance, in the subjective acts of consciousness, of that which surpasses, transcends beyond the individual act of consciousness, and which is grasped as that which is general and ideal, therefore, submitted to "ideation" (a thesis proposed in the Logical Investigations). Husserl acknowledges the meaning of an utterance (a sign) as a certain intentional content of a verbal act and argues that in each verbal act, we can see an element of truth, and that the logical clauses apprehend this truth directly - truth as the accordance of mental content located within a logical proposition (the intentional content of a verbal act, i.e. meaning) with a certain reality. According to Husserl, based on such argument, a certain reality and a specific domain of reality would belong to the meaning of a verbal act, and particularly, to the meaning of a logical proposition. Contrary to the assumptions regarding intentionality and meaning as an intentional content of a verbal act, it would not be a real intentional (psychical) domain, nor - as in terms of the classical definition of truth as presented by Aristotle - a physical reality. Husserl considers a different possibility: a third domain of the ideal objects, i.e. a certain 
"ideal" reality which would be the proper domain of semiotic and semantic references of a language sign and its meaning. These objects are "neither empirical singulars nor classes of singulars: they are ideal objects ideationally apprehended in the correlates of our acts of counting, of inwardly evident judging etc." (Husserl 2001, 119). In the Logical Investigations, which stood as a starting point of Adolf Reinach's phenomenological theses, Husserl indicates the semantic "functional" aspects. After Husserl, they affect the meaning of particular utterances as elements of a logical proposition, and so, references to function and functionality appear alongside the notion of essence. Additionally, the concept of ideation is defined, the theses of which - as noted by Roman Ingarden (cf. Ingarden 1992, lecture 7, 189-190) - would later lose their strength in the Ideas.

In his Logical Investigations, Husserl argued that: "we are dealing with nothing but concepts, whose notion makes clear that they are independent of the particularity of any material of knowledge, and under which all the concepts, propositions and states of affairs that specially appear in thought, must be ordered" (Husserl 2001, 153, § 67 [Begriffe, Sätze, Sachverhalte]). Therefore, notions would be related to certain functions, that Husserl calls the "thought-functions", additionally, connecting them to the functions of particular elements of a logical proposition: "they [the concepts] arise therefore solely in relation to our varying thought-functions: their concrete basis is solely to be found in possible acts of thought, as such, or in the correlates which can be grasped in these" (Husserl 2001, 153). One may say that in the Logical Investigations Husserl closely connected the semantics of the particular elements of a logical proposition with the function that they accomplish, instead of the "material" conceived as the content of a concrete proposition, of a given logical clause referring to a definite object of cognition. Husserl highlights that the semantics of a logical proposition assumes a certain "material", i.e. content indeterminacy, whereas meaning is reduced to that which - as indeterminate - would be possible to think and which may be grasped as "empty". Such argumentation is related to the well known Husserlian thesis concerning the empty semantic intention - the signitive intention of a logical clause as given to be filled by particular subjects. The aim of phenomenological researches would be, i.a. to appoint these notions, their mutual relations and the regularities of their location within a logical proposition, probably functional, and linked with their semantics: "we are concerned with insight into the essence of the concepts involved, looking methodologically to the fixation of unambiguous, sharply distinct verbal meanings. We can achieve such an end only by intuitive representation of the essence in adequate Ideation, or, in the case of complicated concepts, through knowledge of the essentiality of the elementary concepts present in them, and of the concepts of their forms of combination" (Husserl 2001, 153-154).

Here, Husserl is referring to the issues of ideation and essentiality, however, he is discarding the content basis of meaning and, simultaneously, adopts the 
assumption pertaining to the empty semantic intention to be filled. Therefore, the point of reference of the semantic theses is not the assumption concerning the essence conceived in a consequently substantial manner (despite the stance of notional realism), but a conception of ideation related to the functional character of notions in a logical proposition and their functional relationships within a logical proposition. Husserl argues for a certain general unity of meaning that should be pursued by a phenomenological investigator. Husserl defines the general unity of meaning - as that, which is semantically possible and simultaneously necessary, therefore, as that to which one may apply the transcendental argument determining the conditions of the possibility of meaning. The general unity of meaning would be submitted to ideation, i.e. it may be considered that, which is essential in the logical proposition and, simultaneously, "adequate" in terms of any given, determined content of a logical proposition. "But as long as concepts are not distinguished and made clear to ideational intuition, by going back to their essence, further effort is hopeless" (Husserl 2001, 154).

While commenting the theses of Ideas, in his Lectures, Roman Ingarden wrote about Husserl's later departure from the term "ideation": "In the Logical Investigations, it was spoken subsequently, in accordance with species, also about its grasping which was then referred to as 'Ideation'. Ideation was this particular act in which one was able to grasp species, relatively in which it was actually grasped. In the Ideas, the term 'Ideation' vanishes, appearing but a few times in brackets, however, a new enunciation appears: the intuition of essence or the insight of essences (or, the object in its essence perchance) (Wesensschau, Wesenserschauung)" (Ingarden 1992, lecture 7, 189-190). Ingarden stresses many times the changes in Husserl's standpoint and defines his investigative assumptions, as adopted in the Ideas, as "transcendental idealism" (cf. Husserl 1983, 114-117, 365-370). One must add that Husserl's commentaries on Immanuel Kant's conception of ideas are a certain reinterpretation, whereas transcendentalism appears earlier in the Logical Investigations - it concerns the conception of the meaning of a logical proposition and its particular components as a certain "unity of meaning", formal and functional, appointing the conditions of the possibility of appearance of a content-determined ("material") meaning, i.e. that, which is linked with the content of a given, singular logical proposition. Ingarden wrote: "The only thing, which ties the Logical Investigations period Husserl with Plato, is the statement: there are two aspects of being - the real and the ideal'. In the Ideas I, the ideal is still treated as ontologically autonomous, however, the real world is interpreted in the sense of transcendental idealism. In the Formal and Transcendental Logic however, both these aspects of being are grasped as being constituted in experience. They are both 'established'. Therefore, the Ideas I idealism is limited to the aspect of the reality of the world, there is no 'idealism' in reference to ideality or the ontological autonomy of ideal objects" (Ingarden 1992, lecture 9, 263-264), i.e. - according to Ingarden - it is an 
epistemological standpoint linked with the assumptions of transcendentalism, with subjective conditions of cognition and the objects thereof. It would simultaneously be a continuation of the Kantian considerations of ideas in the epistemological context.

\subsection{Immanuel Kant and Edmund Husserl}

One should underline that in his Critique of Pure Reason (Kritik der reinen Vernunft, 1781, 1787), Kant uses among others the term "prototypon" to describe the "ideal", as distinguished from the "idea" ("The transcendental ideal", "prototypon transcendentale"; Kant 1998, 553). In the Critique of Judgment (Kritik der Urteilskraft, 1790), beauty is the Kantian example of an idea as well as an ideal, that is, the result of the idealisation process (Kant 1987, $\S 17$ On the Ideal of Beauty). Beauty as an idea conditions a subjective judgment of taste, while as an ideal (prototypon) it is not considered a presumed, formal, transcendental idea enabling valuation, but rather as a certain temporal, accomplished norm. It allows the characterisation of that which is beautiful not only due to reference to the universal rules of the subjective judgment of taste, but also in reference to a norm established socially for the present. The norm consists of idealisation, therefore it is evaluated as that which is valuable - it becomes socially obligatory and combines the idea of beauty with particular qualities of objects, impressions, images experienced by means of the senses. These qualities are submitted to idealisation; they make it possible to qualify beauty as an ideal accomplished empirically in the creation and reception of works of art. The link between the Kantian concepts of "ideal" and "idealisation" and the Husserlian concept of "ideation" might be subject-matter for another text.

Therefore, conception of meaning, postulated prescriptively by Husserl in his Logical Investigations, assumes a guessed ideal unity of meaning in general, that should be considered by the user of a colloquial language, and he/she would be - by the power of a different, anthropological assumption - a rational subject, i.e. a subject referring to the logical argumentation, and to the calculus of logical propositions. Husserl admits that the unity of meaning is accomplished within the logical proposition which should be "unequivocal", while unequivocality is a result of the idealisation of meaning. Therefore, in the Logical Investigations, the "ideality" of meaning goes beyond the real, individual cognitive and verbal acts, beyond their meanings as intentional content; it is related to the general, transcendent regularities of the appearance and the exposure of meaning (particularly in the acts of expression) and therefore, to a degree, passes beyond the immanence of a concrete, individual subjectivity.

Numerous investigators highlight that ideality in Husserl's phenomenology is apprehended and interpreted in reference to Kant's transcendentalism, allowing 
- both Husserl and his commentators - to make an explicit distinction between the objective and the noematic, as indicated in the Ideas. "Each time that this value of presence is threatened, Husserl will awaken it, will recall it, will make it return to itself in the form of the telos, that is, in the form of the Idea in the Kantian sense. There is no ideality unless an Idea in the Kantian sense is at work, opening the possibility of an indefinite, the infinity of a prescribed progress, or the infinity of permitted repetitions. This ideality is the very form in which the presence of an object in general can be indefinitely repeated as the same. [...] [T]he presence to consciousness will be able to be repeated indefinitely: ideal presence to an ideal or transcendental consciousness. Ideality is the salvation or the mastery of presence in repetition. In its purity, this presence is the presence of nothing that exists in the world; it is in correlation with acts of repetition which are themselves ideal" (Derrida 2011, 8). Ideality is connected with objectivity, however - as it is known - the rational and conscious subjectivity remains the initial point of its definition, both in the Logical Investigations and in the Ideas. The Husserlian thesis concerning an ideal, third domain of reference, of the meaning of verbal acts, may be applied - as noted by Jacques Derrida - exclusively to logical clauses, to logical propositions (cf. Derrida 2011, 86). One must underline that in its generality deriving from a subjective source, Husserl's semantics does not explain the differentiation of meanings of particular utterance, synonymous or unequivocal by definition, provides no aid in characterising the differentiation of semantic intentions related to particular verbal acts. In defence of Husserl's theses and their consistency, one may argue that not every utterance and verbal act aim to be true, however, their truth as a reference to a certain domain of reality is assumed by, always rational, language users.

\subsection{Edmund Husserl and Adolf Reinach}

Similar assumptions appear in the apriori theory of right by Adolf Reinach who - however distinguishing between logical propositions and legal prescriptive provisions - premises the actual existence of the world and the possibility of true predicating upon it. Reinach makes a clear distinction between the descriptive logical propositions, that serve the purpose of considering the two basic possibilities of predication - truth and falsehood, and the prescriptive laws that are duty-imposing and indicate the positive, model-creating norm of action and conduct. (As is known, it is one of Reinach's theses that may later be found in John L. Austin's speech act theory - cf. Mulligan 1987; Smith 1990; Ambroise 2005; Laugier 2005). One may say that the prescriptive clauses define a certain normative, necessary possibility of action, which remains to be a possibility due to the acknowledgement of the free will and of the free actions of particular subjects. Simultaneously, it is a certain possibility concerning 
the contents of legal provisions (that, which is "material" in legal prescriptive clauses) - contents that change, depending on the social and historical context. Reinach writes that: "If one formulates the essential laws of right in such a way that the possibility of their being suspended is taken into their content, then they hold unconditionally. Otherwise their validity depends on those possibilities not being realized. But in either case it remains true that the validity of these laws, considered in themselves, is free from any exception" (Reinach 1983, 114; cf. Reinach 1913, 815).

And normativity as a formal requirement of legal provisions remains a necessity that precedes and transcends history - a necessity, one may add following Husserl, "ideating" the particular given prescriptions along with their content. "What is decisive for the development of law are the given moral convictions and even more the constantly changing economic conditions and needs. And so the propositions found in the positive law are quite essentially different from the propositions proper to science (Wissenschaft)" (Reinach 1983, 2; cf. Reinach 1913, 685). „Just as we sharply stress the independence of the positive law with respect to the apriori theory of right, so we have to stress the independence of the latter with respect to the positive law. There are after all vast areas of social life which are untouched by any positive legal norms [positivrechtlichen Normierung]. Here too we find those specifically legal (as they are usually called) entities and structures, whose independence from the positive law we assert, and here too of course those apriori laws also hold" (Reinach 1983, 6; cf. Reinach 1913, 691).

Ultimately, the Husserlian guessed, "alleged" object of the act of consciousness would be general and ideal, however, the issue of this ideality divides the commentators of the Logical Investigations and the Ideas. According to some investigators, the thesis leads from transcendental idealism to subjective idealism and solipsism (Roman Ingarden), while according to other commentators - it primarily indicates the varying inspirations with Kant's transcendentalism (Jacques Derrida). Other interpretations referring to the Husserlian concept of "ideation", mention the Kantian conception of "ideal" and the neo-Kantian issue of idealisation, widely discussed at the turn of the $19^{\text {th }}$ and the $20^{\text {th }}$ century, i.a. present in works of Ernst Cassirer concerning "symbolic forms" in the twenties, and earlier, in Georg Simmel's theses regarding the idealisation of values (Philosophie des Geldes, 1900), therefore, in a period when Husserl's Logical Investigations and Reinach's aprioristic theory of law were being accomplished. Reinach wrote that: „For we deny emphatically that positive legal norms can be taken as judgments [Urteile] in any sense. The difference between apriori and empirical has no application to them" (Reinach 1983, 5; cf. Reinach 1913, 690). „Together with pure mathematics and pure natural science there is also a pure science of right (reine Rechtswissenschaft), which also consists in strictly apriori and synthetic propositions" (Reinach 1983, 6; cf. Reinach 1913, 691). 
One must stress that according to Reinach originative "laws" are aprioristically presumed and taken in an essentialist manner - they are present in all the beings, observed in nature and described by exact sciences. ,[T]here are eternal laws governing these legal entities and structures, laws which are independent of our grasp of them, just as are the laws of mathematics" (Reinach 1983, 6; cf. Reinach 1913, 690). These originative, aprioristic "laws" would be the basis of the legitimacy of law. In his text Über Phänomenologie (cf. Reinach 1989), Reinach argued that: "Essence intuition is also required in other disciplines. Not only the essence of that which can be realized arbitrarily many times, but also the essence of what is by nature singular and uniquely occurring, requires illumination and analysis" (Reinach 1969). He added: "As there is required an essence theory of the psychical, so also an essence theory of the natural is required. To get such a theory one certainly has to abandon the attitude peculiar to the natural sciences, which of course pursues quite determinate purposes and goals that also are ones especially hard for us to abandon. But here too we must succeed in grasping the phenomena purely, in working out its essence without preconceptions and prejudgments - the essence of color, extension and matter, light and dark, tones, and so on. We must also investigate the constitution of the phenomenal thing, purely in itself and according to its essential structure. In that structure color, for example, certainly plays another role than does extension or matter. Everywhere it is essence laws that are at issue" (Reinach 1969).

\section{REINACH AND THE NORMATIVE ASPECTS OF PROPOSITIONS, PRESCRIPTIONS AND PROVISIONS}

It is well known that Aristotle considered the aim of a logical proposition to be the consideration of the possibilities pertaining to the actual, real being, therefore, a statement regarding the status of an actual, real being is a result of the consideration of the possibilities of predicating on the above-mentioned by means of affirmative and negative propositions. Aristotle (i.a. in Rhetoric) apposes dialectic, i.e. logic pertaining to the contradictory contents, included in two propositions, with rhetoric as a common way of speaking, which main aim is ethically validated influence on the actual, real being, and the appropriate domains of rhetoric are: law (rhetoric pertaining to the matters of the past) and politics (rhetoric pertaining to the matters of the future). Additionally, as is well known, the ontology of the actual, real being (that which is ontic), is supplemented by Duns Scotus with the "proper" ontology of the possible being. Therefore, this possibility regards to the state of a being, and not the knowledge about it as in the Kantian theory that defines the conditions of possibility of subjective reasoning and knowing. According to Edmund Husserl, the normativity of a logical proposition is determined by this possibility of predicating on the state 
of matters in a twofold, true and false, manner. Adolf Reinach however, considers this possibility in reference to legal propositions, simultaneously distinguishing between: a logical proposition as a statement concerning the facts (description) and normative propositions which, regarding his vocabulary, are defined as provisions, therefore, as a kind of prescriptive propositions. As emphasised by Reinach, it is customary for prescriptions to additionally include commands and imperatives - imperative clauses or other language formulas which act as imperatives (e.g. verbless sentences). "The propositions of the apriori theory of right [Die Sätze der apriorischen Rechtslehre] undoubtedly are, insofar as they posit being, asserting propositions, or statements. But this is now our question - is this also true of the propositions of the positive law? One has often claimed that it is; one has more exactly designated legal propositions (Rechtssätze) as hypothetical judgments. A glance at the very first paragraph of our Civil Code shows this view to be untenable. [...] We do not have here a positing of being which, according as this being is really there or not, could be judged as true or false; we rather have an enactment (Bestimmung), which stands beyond the alternative of true or false. [...] The proposition of the jurist [Der Satz des Juristen] can be true or false; quite different predications are appropriate for the enactment of the Civil Code: it can - in the teleological sense - be 'right' or 'wrong,' it can be 'valid' law or 'invalid' law, but never true or false in the logical sense" (Reinach 1983, 103-104; cf. Reinach 1913, 803).

The descriptive logical propositions as statements regarding the facts, refer directly to an actual, real being and to its "state of affairs" (Sachverhalt) - taken solely, they do not posses normative characteristics (the well known argument that the factual state cannot be considered as a model state of the object of predication, is just one of the proposed arguments). However, the provision clauses (formulas) consider proceeding and action in a normative manner, norming the above-mentioned with the an indication of the measure of proceeding, and not only with a measure pertaining to the sole proposition. "Let us now try to go more deeply into the essence of enactments [in das Wesen der Bestimmungen]. The first distinction which comes up here - as by the way also in analogous cases - is the one between the experience of enacting, the act of enacting, the proposition expressing the enactment, the content of the enactment, and the effect of the enactment. If we begin with the individual experiences in which persons enact, we must of course distinguish the experience or the performance of the enactment from the performed enactment itself. [...] This act of enacting [der $\boldsymbol{A k \boldsymbol { t }}$ der Bestimmung] is distinct from the individual experiences of performing the enactment; it is realized in them. The act of enacting has also to be distinguished from the proposition expressing the enactment, which represents a distinct kind of objectivation of the act. It goes without saying that the proposition in this sense does not coincide with the grammatical formulation which we can give it. [...] The proposition, 'Do this' is undoubtedly not a judgment; it is rather related to the act 
of commanding as a judgment is to an assertion. And the enacting proposition, 'A ought to be b,' is related to the act of enacting in exactly the same way. It stands of course in sharp contrast to the judgment, 'A ought to be b,' which expresses the existence of an objective ought-to-be which is grounded in the rightness of A being b. The moralist may perform such acts of judging; the law-giver performs acts of enacting. In the works of ethics we find such asserting or judging propositions; we encounter enacting propositions in the legal codes. There is the general distinction between acts (and propositions [den Sätzen]), and the content to which they refer; between the act of judging (and the judgment [dem Urteilssatze]), and the judged state of affairs; between the command (and the imperative proposition), and what is commanded, etc. Strict relations of essence obtain between these two spheres, and these determine which objects go with which acts. A judgment [Jedes Urteil] - even a false and absurd one - can as judgment refer only to states of affairs. Every command can by its very nature refer only to the action of another person. But an enactment can have both as its object: just as the judgment posits states of affairs as existing, so the enactment can posit that states of affairs ought to exist. But an enactment is also like a command in that its object can be an action; indeed, not only the action of other persons but even one's own action can function as the content of an enactment" (Reinach 1983, 106-107; cf. Reinach 1913, 806-807).

How should norming be described? It is an indication of not the material model of proceeding, but of the formal model - the course of proceeding. One should stress that Reinach used the term "law" (resp. "recht") in a varied, however, not ambiguous manner (logical laws, laws of being, positive law). The author writes about the "theory of right", i.e. "law of rights", therefore, of the rules and principles pertaining to the law itself and the science of law, about the regularities that are eventually to be indicated by an apriori, formal theory of law, postulated in apposition with, i.a. the theory of law based on the history of legal acts and the theories of natural law.

Reinach emphasises on the ontological character of legal provisions repeatedly, because law always remains in certain relations with being and with what is essential in it, as well as with the being admitted as obligatory - the first is assumed by legal provisions, while the second one - as a state of affairs - is assumed within the legal provisions as a model state of being (ontological phenomenology versus transcendental phenomenology - cf. Conrad-Martius 1959; cf. Husserl 1983, 369). „If there are legal entities and structures which in this way exist in themselves, then a new realm opens up here for philosophy. Insofar as philosophy is ontology or the apriori theory of objects, it has to do with the analysis of all possible kinds of object as such. We shall see that philosophy here comes across objects of quite a new kind, objects which do not belong to nature in the proper sense, which are neither physical nor psychical and which are at the same time different from all ideal objects in virtue of their temporality. The laws, too, which hold for these objects are of the greatest philosophical interest. They 
are apriori laws, and in fact, as we can add, synthetic apriori laws" (Reinach 1983, 6; cf. Reinach 1913, 690-691).

One may easily notice that the ontological and the essential in being is a starting point (and a point of argumentation) in establishing the norming legal provisions. The final point (and an aim) of legal provisions is to establish a certain ontological-obligatory status, which now pertains not to what is essential in being, but to the existential - to a specific mode of existence of being, a modus of existence strictly related to the mode of acting, assumed as a model one. "We have here an antithesis (Gegensatz) which runs through the whole world of right. Thus the question at what moment a social act is effective, whether when it is declared, or when its physical embodiment is sent to the other, or when it reaches the other, or only when it is heard by him, has been variously answered by the expression-, the transmission-, the reception-, and the hearing-theory. All of these theories have their basis in pure considerations of practicality [...]. The apriori theory of right must come to understand the essence of legal structures and bring out the strict apriori laws which are grounded in them. Every theory which does not investigate essential being (wesenhaftes Sein) but rather the content of useful norms [zweckmässiger Normen] is absolutely independent of these apriori laws. [...] [W]e also have to insist that one not obscure the purity of the apriori knowledge of being (apriorische Seinserkenntnis) by bringing in practical political points of view. There is in particular no justification at all for introducing any deviating principles which have been established in the development of the positive law, as supposed refutations of self-evident essential laws" (Reinach 1983, 95-96; cf. Reinach 1913, 798).

According to Reinach, obligation is comprehended not in relation to the praxis category, but - as repeatedly emphasised by Reinach - ontologically, i.e. as an obligation resulting from what is essential in being. It is a mode of existence of being, normed by enactments, standing as an accomplishment of its essential features, primarily anthropos as a being, who originally has obligations with regard to own anthropological equipment, first of all to the rationality, and in regard to the fact that it is a "social" being, constructing a community and law as "social acts". The ontological status of norms is defined by Reinach, in reference to values, but also, by acknowledging the norm-constructing and legislative aspects of the human being, as essential features. "If one does not speak of legal propositions as hypothetical judgments, then of course one usually speaks of them as norms [Normen]. But this concept has extraordinarily many meanings [...]. But which one of all of these does one have in mind here? We can make a fundamental demarcation if we reflect on the necessary origin of every enactment. There are norms which are grounded in the moral rightness of states of affairs. Because something is morally right, it ought to be, and if certain further conditions are fulfilled, I ought to do it. This oughtness of being and of doing exists by its nature in itself and apart from the knowing or the positing of any consciousness. An 
enactment, by contrast, necessarily presupposes a person who issues it. Of course even an enactment can have its 'ground' in the rightness of states of affairs. But 'ground' does not mean here that from which the objective ought-to-be derives; it rather designates the motive which moves a person to make an enactment. If one wants to call an enactment a norm, we have here norms which presuppose a person as their origin and bearer. But even after we have marked off our sphere in this way, confusions are still possible. The most usual and most disastrous confusion seems to us to be the one between command and enactment. After all, it seems to be plausible at first glance: legal propositions are norms [Rechtssätze und Normen] which the law-giver issues; and to say that he issues norms is to say that he gives commands, prescriptions, and prohibitions [Befehle, Gebote, Verbote] which are addressed to the citizens or to the executive organs of the legal order" (Reinach 1983, 104-105; cf. Reinach 1913, 804-805).

For the "significance of the norming act" consists in the fact that it is the "primary source" of numerous conventional acts, and they in combination with the former, constitute, e.g. the realm of positive law. The act of norming is a social act, and similar to a promise and a command, it is of an apriori nature, i.e. it includes the apriori aspects, the formal rule-making, however, it does not refer in detail to the contents of law - they are not determined by the inherent, general and common anthropological context, but by the historical and social context. Therefore, positive law in its variety is present and is in force in various societies. "An enactment which tends to conform to that which is, instead of acting out of its own power does indeed come across something here which it can absolutely not do. Of course our position is not that one was conscious of a law of being or even formulated it, and then deduced from this the impossibility of such contracts. The law of being need have had no other influence than the logical laws have, which after all can direct and have directed the thinking of men without becoming fully conscious or even being formulated. And one should not think that when the positive law develops in an 'ontologistic' way, that is, in such a way that its enactments more or less depend on the laws of being, all these laws of being have to be completely recognized. The fact that that which is impossible is not made the object of an enactment, does not imply that all laws of being must be made the objects of enactments" (Reinach 1983, 125; cf. Reinach 1913, 829).

Reinach's polemics with the adherents of natural law (cf. Reinach 1983, 135-136), are simultaneously polemics with theories that grasp the human "nature" broadly, because, according to Reinach, many different possibilities of self-determination in the world, are included within human essence. At the same time, the afore-mentioned are numerous possibilities of existing in the world and that is exactly why they should be normed by legal acts which serve not only as indications but also obligations. One could mention the legal theory of Carlos Cossio, who undertook the task of indicating some model modes of human existence, related to the apriori conditions of rule-making, of law's proclaiming. 


\section{NORMING, NORMALISATION AND STANDARDISATION}

Adolf Reinach admits legal provisions as utterances, that in themselves, contain a possibility of application in situations, thematically differentiated, to norming the conducts of the acting and engaged subjects. Commands and imperatives however, directly indicate the content of a particular, concrete proceeding in a given, specified situation (regarding the apparent facts). "There are neither commands nor enactments which unfold purely within the person; they always address themselves to others, and the need of being heard is intrinsic to them. But whereas commanding is at the same time necessarily an other-directed act, the act of enacting is not. By its very nature every command presupposes a person or group of persons who are commanded, just as with the act of promising or of granting. But enacting does not have this necessary relation to other person, just as little as do acts like waiving or revoking. Although these acts are addressed to other persons in being performed, their substance (Gehalt) lacks any personal moment (personales Moment)" (Reinach 1983, 105; cf. Reinach 1913, 805).

One could ask, whether Reinach apprehended norming as a normalisation of the factual state. It is a certain type of norming, which is in force for everyone, however, what are the possible exceptions? Such exceptions are assumed, due to the freedom postulate and to correlating the freedom of rule-making with the coercive character of commands (imperatives). Normalisation is related to the orders (commands and prohibitions), rather than obligations, i.e. the obligation of a subject in regard to law - to social acts, intersubjective and co-determined by free subjects (social acts and a legal-social act - cf. Reinach 1983, 90; cf. Reinach 1913, 791-792). Positive law is founded due to contracts and conventions, but its source lies in ontological essentialities. However, one may ask Reinach, whether such law serves the standardisation of social life. Positive law is a construction based on essential assumptions, and the relation of law fulfilment - of law that norms our behaviour - is by itself essential for the norm-creating being which is human being. Simultaneously essential, is the freedom of accomplishing law (obligations, duties), as well as, fulfilling orders (imperatives) - this leads to an obvious statement, that the normative standardisation of behaviour (proceeding and acting) would be closer to fulfilling orders (imperatives). One must add that Reinach distinguished between the realistic character of the applied positive law, and the idealisation of its enactments and the act of norming based on them - enactments that may be the basis for orders (imperatives), their legitimacy and legitimisation. "[E]verywhere we encounter this three-fold distinction: the oughtto-be which, existing in itself, makes enactments grounded insofar as they posit it; the ought-to-be which is constituted in the enactment and is valid for a certain group of persons, and which derives from all efficacious enactments, whether grounded or not; and finally, the merely being posited as ought to be, which exists 
relative to all enactments [relativ zu allen Bestimmungen], whether grounded or ungrounded, whether efficacious or inefficacious" (Reinach 1983, 109; cf. Reinach 1913, 809-810).

As is known, descriptive logical propositions have strictly defined formulas of logical clauses. Orders (imperatives) however - within the framework of colloquial language and also specialised languages (e.g. in the case of military orders) - refer to particular grammar formulas and, particularly, occur as imperative clauses (the imperative mood). Reinach considered legal acts (as acts of a specialised language) as social acts, similarly to the acts of fulfilling legal provisions. "We encounter among enactments all the differences which are grounded in the essence of social acts in general. Thus they can issue from several persons, and can be addressed to several persons. In the latter case there is one action which confronts the collective addressees as required and is to be realized by them in common" (Reinach 1983, 109; cf. Reinach 1913, 810).

Reinach considered, i.a. the status of interrogative clauses, in the context of establishing legal provisions and the discussion regarding these provisions. Particularly here, an unstandardised and unfamiliar - logically and grammatically - status of legal provisions, is visible, in comparison to the status of logical prescriptions and imperatives. For the latter are - according to Reinach - submitted to a standardising norming, which possesses essential sources in being, i.e. a strong essential argument, as its legitimisation. He argued that: "If we separate that which essentially is from that which from a moral or from a practical point of view - objectively ought to be, the second does not under all circumstances have to be joined to the first" (Reinach 1983, 111; cf. Reinach 1913, 812). "So we see how the existence of relations of right which result by essential necessity can from another point of view be such that they ought not to be, just as the existence of relations of right which do not result by essential necessity can from another point of view be such that they ought to be. It goes without saying that such an oughtto-be cannot touch apriori being. New factors which eliminate or create existence have to enter the picture, and this is where an enactment comes in. Enactments are conceivable which are made with a view to realizing that which is objectively the case. It may be disputed which social acts were performed by two parties and which effects have resulted from the acts which have been performed" (Reinach 1983, 112; cf. Reinach 1913, 812-813).

\section{THE STATUS OF THE NORM - LEGISLATIVE NORM AND NORM-CREATING LAW}

As mentioned, Adolf Reinach is referring to the essentialist argument, which appears explicitly - in the concept of a primary "law" taken in essentialist terms, as an originative normativity that is binding to all beings. Particularly, 
he refers to anthropological essentialism, the theses of which were present in many conceptions of the times (e.g. Georg Simmel, Ernst Cassirer). Normativity conceived in such an essentialist manner - as a normative source of law socially established by people and for the needs of a given moment in history - would be legislative. Simultaneously, the sole positive law as the source of social normalisation of the actions and conducts, is norm-creating - it defines the content of a norm and the spectrum of its model-creating application. "If one considers rights with regard to the apriori essential laws on the one hand, and with regard to efficacious enactments on the other, one finds very different and in a sense opposed relations. Because certain rights are necessarily grounded in certain social acts, the assertion 'rendering' this state of affairs is correct. Because on the other hand an enactment is efficacious, there exist the rights posited by it. The well-known question as to the priority or posteriority of the 'subjective rights' [subjektiven Rechte] is therefore to be answered differently according as one is thinking of their relation to the essential laws of right or to enactments. When subjective rights exist under certain circumstances with apriori necessity, the corresponding assertions are true. The efficacy of the enactments which posit these rights makes them necessarily exist" (Reinach 1983, 115; cf. Reinach 1913, 816).

Reinach grasps the model-creating aspect of law as "duty imposing", binding to all legal subjects. Therefore, the norm of positive law is historically and socially relative, and as such, is to be examined by history of law. Reinach highlights the separateness of the theory of law in relation to its historical, "genetic" researches, however, he mentions the historical continuity of legal provisions which have - in a given moment -legal sources in the former codifications and are their certain continuation. One may notice that Reinach, while presenting the theses of the apriori theory of right, stresses not its ahistorical but rather its proto-historical aspect. The apriori theory of right comes from essentionalist assumptions concerning the human being as simultaneously rational, norm-creating and legislative (legislative for the needs of social life, of individual existence and conduct), but in order to validate cultural and social relativism of positive law along with its normativity - the sphere of norms apprehended as certain modelcreating meanings.

As is known, Reinach is following the path of Immanuel Kant, defining the apriori conditions of the possibility of positive law. However, simultaneously, in this neo-Kantian investigative procedure, he follows the pointers of Edmund Husserl who - as I already mentioned - proposes the concept of ideas in reference to Kantian regulative ideas anew. Simultaneously, in his investigative procedure, Reinach makes an implicite distinction, typical of the Husserlian phenomenology - a distinction between the formal, static, structural (in Reinach's theory) and the genetic, involved historically. His aprioristic theory of law surpasses the former theory of law, in which one may notice historical aspects, therefore - which would be a structural-genetic theory. Reinach however, proposes a theory that 
is consequently structural and this structural aspect is highlighted on numerous occasions. One must add that during the forming of this theory, the concept of structure (internal build and the external relations between beings, beings and their representations, as well as, representations - mental and cultural, to which legal provisions belong) was widely commented on and specified by numerous investigators and philosophers (i.a. Roman Ingarden and the neo-Kantists, e.g. Ernst Cassirer).

As mentioned, according to Reinach, source-apprehended normativity - originative "laws", aprioristically presumed and taken in an essentialist manner (present in beings and described by exact sciences), would be the basis of the legitimacy of law. These aprioristic and essentialist assumptions finds, in some measure, its continuation in Robert Brandom's theses concerning primarily a normative attitude of human being towards the world, others and oneself (cf. Brandom 1998). As is known, after Brandom, normativity conditions the reference - of not only the ethical subject, but also the subject of cognition - to objects of action and recognition. Not only action, but also cognition would be characterised normatively, with an evaluative aspect.

On the other side however, Jürgen Habermas who would argue i.a. against Brandom, proposed the concept of normativity and legitimacy of law, based on its social "validity" (cf. Habermas 1992, 1996), a contract pertaining to the social hierarchy and the scale of norms that would be the basis for valuation. As already mentioned, Reinach underlined the obligatory character of legal provisions, which may also be defined as their "validity". Nevertheless, it is a validity considered not in the context of social and historical relativism, but rather in the context of anthropological essentialism. Habermas too (similar to Reinach and other phenomenologists of law, e.g. Simone Goyard-Fabre, Paul Amselek; cf. resp. Goyard-Fabre 1972; Amselek 2014; Chérot 2013) assumes the primary rooting of normativity in the sphere of values. He indicates two spheres or domains of valuation and this differentiation would consist of a basic distinction between the positive and the negative. Such two vectors of valuation may be recognised in numerous axiological conceptions, and particularly, in the axiology of Max Scheler (cf. Scheler 1973), who confer an independent status on the negativity, and not the status of that which contradicts positivity. In his aprioristic theory of right, Reinach apprehends the normative, i.e. postulated, model-creating state of the world and of particular beings (in their existence, action and conduct; cf. Gardies 1972) as obligatory, not as much valid but obligating and as such - positive. Breaking the law as a breach of the normativity of legal provisions would not be a confirmation of the alleged negativity. (One may say that Reinach apprehended a disvalue not in the sense of negative value as such, but rather in the meaning of disregard, disesteem of value; cf. Reinach 1912-1913). It would be a confirmation of the positivity of legal provisions in their obligatory character, because they are valid and still obligate all members of a given community. 


\section{BIBLIOGRAPHY}

Ambroise, Bruno. 2005. "Le problème de l'ontologie des actes sociaux: Searle héritier de Reinach?" Les Études philosophiques 1(72): 55-71.

Amselek, Paul. 2014. Mettre le droit en valeurs (Rapport présenté au colloque "La valeur, les valeurs, le droit" organisé le 28 novembre 2014 par le Centre d'études et de recherches sur les contentieux de la Faculté de Droit de Toulon). 1-25. http://paul-amselek.com/textes.php [Accessed 14 February 2017].

Brandom, Robert B. 1998. Making It Explicit. Reasoning, Representing, and Discursive Commitment. Cambridge, MA-London: Harvard University Press.

Cantegreil, Julien. 2005. "D’une voie phénoménologique en théorie du droit. Remarques sur le réalisme d'Adolf Reinach". Les Études philosophiques 1(72): 99-112.

Chérot, Jean-Yves. 2013. "Paul Amselek et la normativité en droit". Revue de la Recherche Juridique - Droit prospectif (Cahiers de Méthodologie Juridique) 38(27): 1997-2009.

Conrad-Martius, Hedwig. 1959. "Die Transzendentale und die ontologische Phänomenologie". In Edmund Husserl, 1859-1959. Recueil commémoratif publié à l'occasion du centenaire de la naissance du philosophe (Phänomenologica, 4). 175-184. Edited by Jacques Taminiaux, Herman L. Van Breda. The Hague: Martinus Nijhoff.

Derrida, Jacques. 2011. Voice and Phenomenon. Introduction to the Problem of the Sign in Husserl's Phenomenology. Translated by Leonard Lawlor. Evanston, IL: Northwestern University Press.

Gardies, Jean-Louis. 1972. Essai sur les fondements a priori de la rationalité morale et juridique. Paris: LGDJ.

Goyard-Fabre, Simone. 1972. Essai de critique phénoménologique du droit. Paris: Klincksieck.

Habermas, Jürgen. 1996. Between Facts and Norms. Contributions to a Discourse Theory of Law and Democracy. Translated by William Rehg. Cambridge, MA: The MIT Press.

Husserl, Edmund. 1983. Ideas Pertaining to a Pure Phenomenology and to a Phenomenological Philosophy - First Book: General Introduction to a Pure Phenomenology. Translated by Fred Kersten. The Hague: Martinus Nijhoff.

Husserl, Edmund. 2001. Logical Investigations. Vol I. Translated by John N. Findlay. London - New York: Routledge.

Ingarden, Roman. 1992. Einführung in die Phänomenologie Edmund Husserls: Osloer Vorlesungen 1967. Gesammelte Werke. Vol. 4. Edited by Gregor Haefliger. Tübingen: Niemeyer.

Kant, Immanuel. 1987. Critique of Judgment. Translated by Werner S. Pluhar. Indianapolis - Cambridge: Hackett Publishing Company.

Kant, Immanuel. 1998. Critique of Pure Reason. Edited and translated by Paul Guyer, Allen W. Wood. Cambridge: Cambridge University Press.

Laugier, Sandra. 2005. "Actes de langage et états de choses: Austin et Reinach". Les Études philosophiques 1(72): 73-97.

Mayrhofer, Philipp. 2005. "Réalisme et fondation chez A. Reinach". Les Études philosophiques 1(72): 3-18.

Mulligan, Kevin. Ed. 1987. Speech Act and Sachverhalt. Reinach and the Foundations of Realist Phenomenology. Dordrecht: Martinus Nijhoff.

Reinach, Adolf. 1912-1913. "Die Überlegung: ihre ethische und rechtliche Bedeutung". Part I. Zeitschrift für Philosophie und philosophische Kritik 148: 181-196.

Reinach, Adolf. 1912-1913. "Die Überlegung: ihre ethische und rechtliche Bedeutung". Part II. Zeitschrift für Philosophie und philosophische Kritik 149: 30-58.

Reinach, Adolf. 1913. "Die apriorischen Grundlagen des bürgerlichen Rechtes". In Jahrbuch für Philosophie und phänomenologische Forschung 1(2): 685-847. 
Reinach, Adolf. 1969. "Concerning Phenomenology". Translated by Dallas A. Willard. Pacific Philosophical Quarterly (50)2: 194-221. www.dwillard.org/articles/individual/concerningphenomenology-trans.-of-adolf-reinachs-ueber-phaenomenologie [Accessed 5 January 2018]. Reinach, Adolf. 1983. "The Apriori Foundations of the Civil Law". Translated by John F. Crosby. Aletheia. An International Journal of Philosophy 3: 1-142.

Reinach, Adolf. 1989. "Über Phänomenologie". In Sämtliche Werke: Textkritische Ausgabe in 2 Bänden. 531-550. Edited by Karl Schuhmann, Barry Smith. München: Philosophia Verlag.

Scheler, Max. 1973. Formalism in Ethics and Non-Formal Ethics of Values. Translated by Manfred S. Frings, Roger L. Funk. Evanston, IL: Northwestern University Press.

Simons, Peter. 1995. "Meaning and Language". In The Cambridge Companion to Husserl. 106-137. Edited by Barry Smith, David W. Smith. Cambridge, UK: Cambridge University Press.

Smith, Barry. 1990. "Towards a History of Speech Act Theory". In Speech Acts, Meaning and Intentions. 29-61. Edited by Armin Burkhardt. Berlin: Walter de Gruyter. 